\title{
Dossiê 100 anos da Revolução Russa
}

É com grande satisfação que apresentamos mais esta edição da RUS - Revista de Literatura e Cultura Russa. O número 10, dedicado em especial ao centenário da Revolução Russa, contou com uma quantidade significativa de contribuições sobre vários aspectos desse relevante acontecimento da história mundial que, após derrubar a monarquia russa e o governo provisório, estabeleceu com o poder soviético o primeiro estado socialista. A democracia radical que a revolução de 1917 representava, e que provocou mundo afora uma extraordinária atmosfera de inquietude e renovação nos campos social, político e cultural, foi esmagada pela difícil realidade dos primeiros anos, culminando na gradual cristalização de uma ditadura burocrática que durou até 1991. Ainda assim, seu exemplo permanece como referência em todo o mundo.

Começamos este Dossiê com um artigo que propõe uma nova categoria para descrever a Revolução Russa de 1917: "revolução democrática antiburguesa". Nele o autor defende que o "poder soviético" foi proclamado, de fato, durante a Revolução de Fevereiro, em 1917, com o objetivo central de realizar o vasto programa de reformas anteriormente denominado pela expressão "revolução democrática" - antes de mais nada, terra para os camponeses e liquidação da aristocracia rural enquanto classe.

Como uma amostra da imensa riqueza que a cultura russa trouxe então ao mundo, o segundo artigo aborda um outro aspecto da Revolução, relativo à nova concepção de arte e cultura e às tantas experiências estéticas geradas nesse agitado momento histórico. Nele a autora destaca o surgimento de muitos jovens artistas russos que se tornaram verdadeiros representantes da nova era proletária, ao concretizar uma visão de arte voltada a construir uma nova realidade.

O artigo seguinte salta para um momento já posterior da Revolução e apresenta um quadro das atividades grevistas de 1922 a 1932, destacando o "compromisso" alcançado entre trabalha- 
dores e o Estado no período soviético inicial, durante a Nova Política Econômica, posteriormente enfraquecido em função das medidas tomadas contra a classe trabalhadora durante $o$ rápido processo de industrialização. No artigo, o autor apresenta evidências estatísticas sobre frequência, número de participantes e resoluções da atividade grevista, assim como os distúrbios entre os trabalhadores durante esse período final.

Avançando para o século XXI, o quarto artigo aborda o fenômeno da "nostalgia soviética" na Rússia contemporânea, que se evidencia não só em relação à cultura, à estética e ao modo de vida, como ao passado soviético como um todo. $O$ autor procura mostrar também como se dá a utilização desse fenômeno por parte do Estado russo no sentido da criação de uma nova ideia nacional russa, baseada na unidade nacional e no patriotismo conservador.

Abordando um outro aspecto dessa questão, relativo à influência da memória cultural na política da memória, o último artigo do Dossiê procura evidenciar a absoluta ausência, na Rússia, de eventos relevantes ligados às comemorações do centenário da Revolução por parte das altas esferas oficiais. Daí, para o autor, o papel de destaque que a política da memória adquire em decorrência da limitação da política pública, já que a avaliação sobre as consequências da revolução por parte dos cidadãos russos é contraditória e pouco mudou desde 1990 , sendo que a maioria nega a possibilidade de uma nova revolução.

Em 2017, o Programa de Literatura e Cultura Russa da USP comemorou também o centenário de nascimento de Boris Schnaiderman e o centenário da publicação do texto "A arte como procedimento", de Victor Chklóvski, festejado em muitos países. Por isso, publicamos neste número da RUS um artigo dedicado a Boris Schnaiderman, em que a autora analisa as diferenças entre marxismo e estruturalismo no que se refere, em particular, a como se dá a inserção da obra literária no âmbito da cultura e analisa os conceitos de "amplificação" de A. K. Jolkóvski e de "fiç̧ão e realidade" de Ruy Coelho.

Esta belíssima edição contou ainda com um ensaio sobre a antrozoologia no conto Kholstomér, de Tolstói, que narra as re- 
lações de um cavalo com seres humanos a partir do ponto de vista do animal. Para a análise dessa interação, a autora destaca o procedimento da arte como estranhamento dos objetos, que, segundo a teoria desenvolvida por Chklóvski em seu texto "A arte como procedimento", consiste em obscurecer a forma e aumentar a dificuldade e a duração da percepção.

Para finalizar, este número traz também uma entrevista relacionada ao tema de nosso Dossiê, realizada com o professor e cientista Bernardo Boris Vargaftig, que desenvolveu pesquisas no ramo da farmacologia que o colocaram às portas do Prêmio Nobel de Medicina de 1982. A entrevista com Vargaftig foi realizada por ocasião do lançamento de sua tradução do livro Minha vida, obra autobiográfica de Leon Trótski, que culminou com as comemorações do centenário da Revolução Russa de 1917.

Boa leitura!

Fátima Bianchi

Editora Rus 